\title{
Table of Illustrations
}

We acknowledge the courtesy of the sources listed here for authorizing the reproductions.

\section{VOLUME I}

1. Illustration from Gaspar de San Agustín's Conquistas de las islas Philipinas (Madrid 1698), depicting the complementary nature of the spiritual and the temporal conquest of the islands. San Agustin, O.E.S.A., was in the Philippines from 1668-1724, and this work covers the period 1511-1614.

2. The earliest European picture of Indians with some ethnographic accuracy: Tupinambas of coastal Brazil in a 1505 woodcut, now in Munich. Bayerische Staatsbibliothek, Munich.

3. Woodcuts by Hans Burgkmair, 1516-19, in The Triumph of Maximilian I. Tupinamba men and women wearing feather skirts. (From the atlas supplement to Jahrbuch der kunsthistorischen Sammlungen des allerhöchsten Kaiserhauses 1, Vienna 1883-84).

4. A Tupinamba man drawn by Albrecht Dürer in 1515. Bayerische Staatsbibliothek, Munich.

5. Indians in feather costumes collecting brazilwood, Millar Atlas of about 1519. Bibliothèque Nationale, Paris.

6. Method of starting fire with a palm drill, as used by the Indians of the Antilles and Panama, in a drawing by Oviedo, before 1557 . The Huntington Library, San Marino. 


\section{Table of Illustrations}

7. A rectangular type of Indian house on Hispaniola, in a drawing by Oviedo, before 1557. The Huntington Library, San Marino.

8. An Aztec man at the court of Charles V in 1529, in a watercolor by Christoph Weiditz. Germanische Nationalmuseum, Nuremberg.

9. An Aztec nobleman at the court of Charles V in 1529, in a watercolor by Christoph Weiditz. Germanische Nationalmuseum, Nuremberg.

10. Tupinambas on Jean Rotz' 1542 map of Brazil, including many accurate ethnographic details. British Library.

11. Brazilian Indians, probably Tupinambas, and their houses and palisade, on the map by Pierre Desceliers, 1546. John Rylands University Library of Manchester.

12. Indians in northeastern South America, on a 1547 map by Nicolas Vallard. The Huntington Library, San Marino.

13. Man from the Guatemala coast, 1553, Codex Tudela. Photo Museo de América, Madrid.

14. Aztec woman preparing chocolate, 1553, Codex Tudela. Photo Museo de América, Madrid.

15. The Inca emperor in a woodcut published in 1553 by Pedro de Cieza de León. Library of Congress.

16. Cuzco as a European town, with an Inca at left, in a woodcut published in 1553 by Pedro de Cieza de León. Library of Congress.

17. Indians on a 1555 map of Brazil by Guillaume Le Testu. Bibliothèque, Ministère de la Guerrr, Paris. Photo Giraudon.

18. "Les Canibales," probably Potiguara Indians in northern Brazil, on a 1555 map by Guillaume Le Testu. Bibliothèque, Ministère de la Guerre, Paris. Photo Giraudon.

19. An Indian on snowshoes, on a 1555 map of North America by Guillaume Le Testu. Bibliothèque, Ministère de la Guerre, Paris. Photo Giraudon.

20. Indians of coastal Brazil shown on a woodcut map published by Ramusio in 1556. Library of Congress.

21. Tupinamba men with feather ornaments, lip and cheek plugs, necklace, body tatooing, typical club, bow and arrows, in a woodcut published by Hans Staden in 1557. The John Carter Brown Library, Brown University, Providence.

22. Tupinamba sacrifice of a captive for a cannibal feast, in a woodcut published by Hans Staden in 1557-the prototype for an extended series by other artists. The John Carter Brown Library, Brown University, Providence.

23. Thevet's woodcut of Tupinambas smoking a cigar and starting a fire with a hand drill of exaggerated size. Les singularitez, 1557, fol. 101r. Library of Congress. 
24. The Tupinamba custom of greeting a visitor or a returning member of their community with weeping, in Thevet's woodcut. Les singularitez, 1557 , fol. $85 \mathrm{v}$. Library of Congress.

25. Tupinamba execution of a captive, in an illustration derived from the woodcut by Staden shown in fig. 22. Thevet, Les singularitez, 1557, fol. 76v. Library of Congress.

26. Paracoussi, king of the Río de la Plata, according to a portrait published by André Thevet, Les vrais pourtraits, 1584, fol. 656r . Library of Congress.

27. Indians of the Colombia-Panama coast pouring molten gold down the throats of Spaniards, then butchering and eating them. Benzoni's caption (Historia del mondo nuovo, 1572, fol. 49v) notes that the penis sheaths are part of their usual attire. Library of Congress.

28. Woodcut on a 1566 handbill advertising the public exhibition in Europe of an Eskimo woman and her daughter. British Library.

29. Woodcut based on the group of Eskimos with a kayak brought to England by Martin Frobisher in 1577; from Dionyse Settle's French account. Copyright British Library.

30. A Frenchman and a Tupinamba woman engaged in the weeping greeting as depicted by Jean de Léry in 1578, improving on an earlier engraving published by Thevet (see fig. 24).

31. The village of Pomeiooc in coastal North Carolina, as painted by John White about 1588. British Museum.

32. An Indian dance at the village of Secoton, coastal North Carolina, on 15-16 July 1585, as painted by John White about 1588 . British Museum.

33. Mexican mask. Rome, Museo Preistorico Etnografico Luigi Pigorini.

34. Mexican mask. Rome, Museo Preistorico Etnografico Luigi Pigorini.

35. Mexican sacrificial knife. Woodcut in U. Aldrovandi, Musaeum metallicum (Bologna 1648).

36. Stone knife. Woodcut in U. Aldrovandi, Musaeum metallicum (Bologna 1648).

37. Mexican heads and spindle whorl. Woodcut in U. Aldrovandi, Musaeum metallicum (Bologna 1648).

38. Mexican heads and figurines. Woodcut in U. Aldrovandi, Musaeum metallicum (Bologna 1648).

39. St. Ambrose, featherwork picture. Loreto, Treasury of the Santa Casa.

40. St. Jerome, featherwork picture. Loreto, Treasury of the Santa Casa.

41. St. Augustine, featherwork picture. Loreto, Treasury of the Santa Casa.

42. St. Gregory, featherwork picture. Loreto, Treasury of the Santa Casa. 
43. Mexican god. Woodcut in Lorenzo Pignoria, Imagini degli dei indiani (Appendix to Cartari, Venice 1647).

44. Mexican god. Woodcut in Lorenzo Pignoria, Imagini degli dei indiani (Appendix to Cartari, Venice 1647).

45. Uexotzincatl (from Codex Telleriano-Remensis, fol. 43).

46. Motecuhcomatzin (from Codex Vaticanus A, 3738, fol. 60).

47. Sacrificial knife handle. Rome, Museo Preistorico Etnografico Luigi Pigorini.

48. Sacrificial knife handle. Rome, Museo Preistorico Etnografico Luigi Pigorini.

49. Two sacrificial knife handles. Woodcut in Lorenzo Legati, Museo Cospiano (Bologna 1677). Photo Biblioteca Vaticana.

50. Two American gods. Engraving (detail) in Filippo Bonanni, $\mathbf{M u -}$ saeum Kircherianum (Rome 1709). Photo Biblioteca Vaticana.

51. Mexican sacrificial knife. Woodcut in Fortunio Liceto, Pyronarcha (Padua 1634). Photo Biblioteca Vaticana.

52. Native Mexican manuscript paintings. Codex Nuttall, page 9. British Museum.

53. Native Mexican manuscript paintings, Codex Mendoza, fol. $67^{r}$. Bodleian Library, Oxford, MS Arch. Seld. A.1.

54. Codex Florentino, Book VIII. Closer to native style. Laurentian Library, Florence.

55. Codex Florentino, Book VIII. Closer to native style. Laurentian Library, Florence.

56. Codex Florentino, Book IX. More Europeanized style. Laurentian Library, Florence.

57. Codex Florentino, Book IX. More Europeanized style. Laurentian Library, Florence.

58. Fresco by Ludovico Buti, 1588. Florence, Uffizi Palace, detail from ceiling of the Armoury (after Detlef Heikamp, "Les Médicis et le Nouveau Monde," L'Oeil 144 [1966] 17). Photo P. E. Nufer, UCLA Media Center.

59. Notebook probably by Felippe de Winghe, fol. 58r. Biblioteca Angelica, Rome, nos. 1564 and 1551.

60. West Indies Landscape by Jan Mostaert, ca. 1523-25 (Haarlem, Frans Hals Museum).

61. Window Rock, Arizona.

62. The West Indies Landscape by Jan Mostaert.

63. Detail from West Indies Landscape by Jan Mostaert.

64. Detail from West Indies Landscape by Jan Mostaert.

65. Detail from West Indies Landscape by Jan Mostaert.

66. Horsemen in feather skirts. Etching from Balthasar Küchler, Repraesentatio der Fürstlichen Auffzug und Ritterspil... (1611). The Metropolitan Museum of Art, Harris Brisbane Dick Fund. 
67. Festivities in the Place Royale celebrating the engagement of Louis XIII of France and Anne of Austria, April 1612. Engraving by Jan Ziarnko. Bibliothèque Nationale, Paris.

68. Floats, horsemen, and Moor in feather skirt, Heidelberg 1613. The Metropolitan Museum of Art, The Elisha Whittelsey Collection.

69. Figure probably representing America. Watercolor from a tournament book, Nuremberg, late sixteenth century. The Metropolitan Museum of Art Library.

70. Indian. Drawing by Giulio Parigi, early seventeenth century. Biblioteca Marucelliana, Florence.

71. Indians and parrots. Etching by Valerio Spada from Giovanni Battista Balbi, Balletti d'invenzione nella finta pazza, about 1645 . The Metropolitan Museum of Art, The Elisha Whittelsey Collection.

72. Moors. Detail from etching by Caspar Merian from Solemnia electionis et inaugurationis Leopoldi . . . (Frankfort 1660). The New York Public Library, Spencer Collection.

73. Indian drummer and trumpeter. Engraving by François Chauveau from Ch. Perrault, Courses de testes et de bagues faites par le roy . . . 1662 (Paris 1670). The Metropolitan Museum of Art, Harris Brisbane Dick Fund.

74. The duke of Guise as American king. Pl. 59 from Courses de testes et de bagues... 1662.

75. Indians hunting parrots. Drawing by Daniel Rabel for the Ballet de la Douairière de Billebahaut, about 1626. Cabinet des Dessins, Louvre, Paris.

76. Triumphal Arch. Woodcut from Giovanni Alberto Albicante, Trattato del'intrar in Milano di Carlo V . . . (Milan 1541). The New York Public Library, Spencer Collection.

77. Arch of the Lusitanians. Etching by Van der Borcht from Johannes Bochius, Descriptio publicae gratulationis . . . in adventu . . . Ernesti Archiducis Austriae (Antwerp 1595). The Metropolitan Museum of Art, Rogers Fund.

78. Brazilians in a forest. Woodcut from C'est la déduction du sumptueux ordre plaisantz spectacles et magnifiques théâtres dressés, et exhibés par les citoiens de Rouen . . . (Rouen 1551). The Metropolitan Museum of Art, Purchase, Anne and Carl Stern Gift.

79. Ship of Amerigo Vespucci. Etching by Remigio Cantagallina from Giulio Parigi, Comedia rappresentata nelle nozze del . . . Principe di Toscana ([Florence] 1608). The Metropolitan Museum of Art, Harris Brisbane Dick Fund.

80. Indians and Europeans using tobacco. Drawing by Filippo d'Aglié for the ballet Tobacco. 
81. King Ferdinand viewing Columbus' discovery of 1492 , as shown in an often-copied illustration which first appeared in a poetic rendering of the exploration, printed in Rome in 1493.

82. King Ferdinand of Spain with entourage and Jesus Christ, a misleading woodcut in a report on the Columbus voyages printed in 1497.

83. German newsletter with largely irrelevant illustrations, reporting voyage to Yucatan (1521) as well as the Turkish threat, probably published in 1522.

84. Czech view of Vespucci sailing to the New World (1505).

85. Indian couple as reported in an edition of Cortés, Antwerp, 1523. Habsburg coat of arms at upper center.

Figures 86 to 96 courtesy of James Ford Bell Library, University of Minnesota.

86. The geocentric image. Atlas carrying the universe. Johannes Schoner, Opusculum geographicum . . . (Nuremberg 1533).

87. The heliocentric image. The new harmony of the universe. Nicholas Copernicus, De orbium coelestium revolutionibus (Nuremberg 1543).

88. Example of a Greek Ptolemy manuscript, end of twelfth century, from Victor Langlois, Geographie de Ptolémée (Paris 1867).

89. Fool with compass. Sebastian Brant, Stultifera navis (Nuremberg 1497).

90. Title page of Bernard Varen (Varenius), Geographia generalis (Amsterdam 1650).

91. A T-O map of the ninth century. Reproduced from C. Raymond Beazley, The Dawn of Modern Geography (London 1897).

92. An example of simple geometric presentation of the world. Joannes de Sacro Bosco, Sphera mundi (Venice 1499).

93. The North Pole presented according to the quaternary principle. Gerhardus Mercator, Septemtrionalium terrarum descriptio (Duisburg 1595).

94. The Seal of Nicholas Copernicus. Reproduced from Stanislav Mossakowski, "The Symbolic Meaning of Copernicus' Seal," Journal of the History of Ideas 34 (1973) 452.

95. King Manuel I of Portugal rides around the Cape of Good Hope. Waldseemüller's carta marina, edited by Lorenz Fries (Strasbourg 1525).

96. Antipodes in the sixteenth century. Münster, Cosmographia (Basel 1544).

97. Mountain crests serve as symbols to indicate divides between 


\section{Table of Illustrations}

drainage basins. From the Mercator map of 1569 , as drawn by Noël L. Diaz for the Announcement of the International Conference "First Images of America: The Impact of the New World on the Old."

98. Wild man and his wife, Epistola Albericii, De novo mundo (Rostock ca. 1505).

99. Wild man and his wife, Van der niewer wereld (Antwerp ca. 1508).

100. Cannibal preparing one of Vespucci's men for a meal, Kunstmann II map, 1502. Bayerische Staatsbibliothek, Munich.

101. Brazilians at home, "Munich" woodcut, 1505 or 1506. Bayerische Staatsbibliothek, Munich.

102. Derivative Brazilians, J. Van Doesborch, De nouo mondo (Antwerp ca. 1520).

103. Map with canibali in Ptolemy, Geographia, ed. S. Münster (Basel 1540).

104. Cannibals in Brazil. P. Apian, Cosmographia, ed. G. Frisius (Antwerp 1545).

105. Castles in the New World, Paesi nouamente retrouati (Venice 1507).

106. Castles in the Indies, Epistola Christofori Colombi (Basel 1493,

107. Castles in Hispaniola, 1493, C. Columbus, De insulis in mari Indico repertis (Basel 1494).

108. Tenochtitlan with castles, in Cortés, Praeclara (Nuremberg 1524).

109. World Map from the Latin edition of Ptolemy's Geographia (Ulm 1482).

110. Martin Behaim's Erdapfel; gores of the globe and polar caps, 1492.

111. Sketch map by Christopher Columbus of the coast of Hispaniola, 1493.

112. Manuscript map by Alessandro Zorzi, ca. 1500, showing insular Central America and the north coast of South America between Eurasia and Eurafrica.

113. Detail of the portolan chart by Juan de la Cosa, 1500: the east coast of America.

114. First printed mappamundi showing the New World, by Giovanni Contarini, 1506.

115. Print of the first map with the name 'America'; a woodcut by Martin Waldseemüller, 1507.

116. Graticule of one type of cordiform projection, formalized by Johannes Werner, 1514 (Drawn by Noël L. Diaz).

117. Map of the Caribbean from Peter Martyr's Occeani Decas, 1511.

118. Detail of a manuscript chart showing the Americas, by Diego Ribeiro, 1529.

119. Manuscript map by Battista Agnese showing the track of Magellan's Vitoria, 1536.

120. Engraved world map by Gerhardus Mercator, 1569, on the conformal projection which bears his name. 
121. Engraved map of Chesapeake Bay, 1612, resulting from the survey by Captain John Smith, 1608.

122. Engraved world map by Edmond Halley, 1702, showing isogones in the Atlantic and Indian Oceans and seventeenth-century discoveries; California appears as an island.

123. Flight navigation chart, 1971.

124. Flight navigation chart, 1974.

125. Navigational triangle.

126. Tabula prima solis.

127. Residuum tabulae primae solis.

128. Tabula declinationis. Tabula equationis.

\section{LOCATION OF PLATES}

The plates are identified in the text by a small asterisk: fig. ${ }^{*} 70$. The table below will help to locate them.

Figures

$2,5,8,9,10,11$

$12,13,14,17,18,19,26$

$31,32,33,34,39,40$

$47,48,52,53$

$58,59,60,61,66,68,69,70,73$

$74,75,77,78,80$

88,93

94,104

$97,110,115,120$ following page

424

440

456

472

488

504

622

638

654 